\title{
Sawdust Derivative for Environmental Application: Chemistry, Functionalization and Removal of textile dye from aqueous solution
}

\author{
THAIS F. PINTO' ${ }^{1}$, CÍCERO W.B. BEZERRA ${ }^{1}$, DOMINGOS S.A. SILVA ${ }^{1}$, EDSON C. DA SILVA FILHO ${ }^{2}$, ADRIANA \\ P. VIEIRA ${ }^{3}$, CLAUDIO AIROLDI ${ }^{3}$, JÚLIO C.P. DE MELO ${ }^{3}$, HILDO A.S. SILVA ${ }^{1}$ and SIRLANE A.A. SANTANA ${ }^{1}$ \\ ${ }^{1}$ Departamento de Química/CCET, Universidade Federal do Maranhão, Avenida dos \\ Portugueses, s/n, Campus do Bacanga, 65080-540 São Luís, MA, Brasil \\ ${ }^{2}$ Centro de Ciências da Natureza, Universidade Federal do Piaú, Avenida Universitária, s/n, \\ Campus Universitário Ministro Petrônio Portella, 64049-550 Teresina, PI, Brasil \\ ${ }^{3}$ Instituto de Química, Universidade Estadual de Campinas, Rua Carlos Gomes, 241, \\ Cidade Universitária Zeferino Vaz, 13083-970 Campinas, SP, Brasil \\ Manuscript received on December 17, 2014; accepted for publication on March 1, 2016
}

\begin{abstract}
The adsorption of Violet Remazol 5R (VR 5) on wood sawdust modified with succinic anhydride (SSA) as a function of contact time, $\mathrm{pH}$, and initial dye concentrations was investigated using a batch technique under ambient conditions. The SSA obtained was confirmed by IR spectroscopy, thermogravimetry and ${ }^{13} \mathrm{C}$ NMR, and degrees of substitution (DS) were calculated. A study on the effect of the $\mathrm{pH}$ on the adsorption of VR 5 showed that the optimum $\mathrm{pH}$ was 2.0. The interactions were assayed with respect to the pseudofirst-order and pseudo-second-order kinetic models, and were found to follow closely the pseudo-secondorder. The isotherm was adjusted to the Langmuir, the Freundlich and the Temkin sorption models. SSA is a promising material for the removal of dye textile from aqueous solutions, and under conditions studied the removal percentage achieved was $51.7 \%$.
\end{abstract}

Key words: wood sawdust, adsorption, textile dye, succinic anhydride.

\section{INTRODUCTION}

Environmental pollution, in general, is one of the most serious problems faced by society and is directly linked to industrial development, with textile activities accounting for the worsening of the situation, generating a significant amount of colored wastewater (Crini 2006). Besides their natural toxicity, dyecontaining effluents in a water course affect the process of photosynthesis, with serious and undesirable consequences to aquatic and human life (Kadirvelu et al. 2003, Dinçer et al. 2007, Shen et al. 2009).

Conventional methods used to remove dye from industrial effluents include biodegradation, Fenton and photo-Fenton oxidations, electroflocculation, combined photo catalytic and ozonation processes, coagulation, and adsorption (Yagub et al. 2014). However, these methods are not very successful due

Correspondence to: Sirlane Aparecida Abreu Santana

E-mail: sirlane@ufma.br 
to several restrictions (Sulak et al. 2007, Gupta and Suhas 2009). Among these treatment technologies, adsorption technology is currently under application and investigative research because it provides a simple, fast, efficient, and economical means to restore polluted areas and to treat wastewater as well (Crini 2006, Yagub et al. 2014).

Most commercial systems currently use activated carbon as a sorbent to remove dyes from wastewater due to its excellent adsorption ability. However, although activated carbon is a preferred sorbent, its high cost prevents a widespread use (Crini 2006, Yagub et al. 2014). Alternatively, agricultural wastes have been reported as adsorbents to dye removal (Crini 2006, Gupta and Suhas 2009, Rafatullah et al. 2010, Salleh et al. 2011, Sharma et al. 2012, Bharathi and Ramesh 2013, Sanghi and Verma 2013, Kyzas and Kostoglou 2014). The materials tested as dye adsorbents include sphagnum moss peat (Ho and Mckay 1998), wheat bran (Çiçek et al. 2007), silkworm pupa (Noroozi et al. 2007), babassu coconut mesocarp (Vieira et al. 2009), pistachio hull waste (Moussavi and Barikbin 2010) and babassu coconut epicarp (Vieira et al. 2011); however, in some situations the sorption capacity of native agricultural by-products was found to be low. In order to improve the sorption capacity of these biomaterials, agricultural by-products have been chemically modified with different reagents and methods. Most materials obtained from chemical modification have been used to remove metals (Randall et al. 1978, Okieimen and Okundaye 1989, Laszlo and Dintzis 1994, Wartelle and Marshall 2000, Vieira et al. 2010), while dye removal is covered by few reported studies. Some studies have reported modification of lignocellulosic materials to remove cationic dyes (Gong et al. 2006, 2007, Mao et al. 2010).

The objectives of this work were to convert wood sawdust into a new anionic sorbent with high sorption capacity, and to examine the potential application of this new sorbent in dye wastewater treatment. Chemical modifications of wood sawdust were conducted by reaction with succinic anhydride (Melo et al. 2011). After characterization of the resulting material, its ability to remove the Violet Remazol 5R (VR 5) dye from aqueous solution was investigated. The influence of $\mathrm{pH}$, time, and dye concentration in the isothermal kinetic modeling has been considered.

\section{MATERIALS AND METHODS}

The VR 5 dye was provided by Indústria de Toalhas São Carlos, from the state of São Paulo, Brazil. The dye was a chemical product of analytical grade and was used without further purification. The wood sawdust was crushed to result in particle sizes in the 0.088-0.177 mm range. N,N'-dimethylacetamide (DMA) (Synth) and the succinic anhydride (SA) (Aldrich), ethanol (Synth), hydrochloric acid (Synth), and sodium hydroxide (Nuclear) were all of analytical grade.

PREPARATION OF THE SORBENT

The wood sawdust was chemically modified by reaction with succinic anhydride in the absence of solvent (Melo et al. 2011). A sand bath was previously stabilized at a temperature above $391 \mathrm{~K}$. A reaction flask containing $31.0 \mathrm{~g}$ of succinic anhydride was immersed in a sand bath and maintained under magnetic stirring, until the merger of the same. After the merger, $5.0 \mathrm{~g}$ of wood sawdust were dumped into the flask and left to react for $20 \mathrm{~min}$. Throughout the procedure the balloon was closed by a silica gel drying tube to prevent hydrolysis of the anhydride. At the end of the reaction, N,N'-dimethylacetamide (DMA) was added to the mixture at a 6:1 ratio between DMA and anhydride to remove non-reacted anhydride, which solidifies 
when cooled during filtration. Then, it was filtered hot and washed with distilled water. The material was dried for $24 \mathrm{~h}$ at $298 \mathrm{~K}$ and denominated SSA.

\section{MEASUREMENTS}

Infrared spectra were obtained by accumulating 32 scans in the $4000-400 \mathrm{~cm}^{-1}$ range on a MB-Bomem FTIR spectrophotometer using $\mathrm{KBr}$ pellets with a resolution of $4 \mathrm{~cm}^{-1}$. Solid state ${ }^{13} \mathrm{C}$ NMR spectra of the samples were obtained on a Bruker AC 300/P spectrometer. The CP/MAS technique was used. The measurements were obtained at $75.47 \mathrm{MHz}$ frequencies, with magic angle spinning of $4 \mathrm{kHz}$ with pulse repetition of $5 \mathrm{~s}$ and contact times of $1 \mathrm{~ms}$.

Thermogravimetric curves (TG) were carried out with a Shimadzu TGA-50 instrument under a nitrogen flow rate of $0.50 \mathrm{~cm}^{3} \mathrm{~s}^{-1}$, in the temperature interval from 298 to $1000 \mathrm{~K}$, with a heating rate of $0.167 \mathrm{~K}$ $\mathrm{s}^{-1}$ for a sample mass of about $10 \mathrm{mg}$. The experiments of the visible spectrophotometry were carried with VARIAN-AA 50 instrument.

\section{DEGREE OF SUBSTITUTION}

The amount of carboxylic functions attached to the SSA surface was determined through retrotitration. For this purpose, $0.1000 \mathrm{~g}$ of each material was treated with $0.100 \mathrm{dm}^{3}$ of $400.0 \mathrm{mg} \mathrm{dm}^{-3}$ sodium hydroxide solution for $1 \mathrm{~h}$ under constant magnetic stirring. The solid was separated by filtration and three aliquots of $0.020 \mathrm{dm}^{3}$ of each solution obtained were titrated with $365.0 \mathrm{mg}$ $\mathrm{dm}^{-3}$ aqueous hydrochloric acid (Gurgel et al. 2008). The concentration of the carboxylic function was calculated by Eq. (1):

$$
\mathrm{C}_{\mathrm{COOH}}=\frac{\left[\left(\mathrm{C}_{\mathrm{NaOH}} \mathrm{xV}_{\mathrm{NaOH}}\right)-\left(5 \mathrm{xC}_{\mathrm{HCl}} \mathrm{xV}_{\mathrm{HCl}}\right)\right]}{\mathrm{m}_{\text {mat }}}
$$

where $\mathrm{C}_{\mathrm{NaOH}}$ and $\mathrm{C}_{\mathrm{HCl}}$ are the concentrations of hydroxide and acid $\left(\mathrm{mg} \mathrm{dm}^{-3}\right), \mathrm{V}_{\mathrm{NaOH}}$ and $\mathrm{V}_{\mathrm{HCl}}$ are the volumes of initial hydroxide and hydrochloric acid $\left(\mathrm{dm}^{3}\right)$ used in the titration of the excess of non-reacted base, and $\mathrm{m}_{\mathrm{mat}}(\mathrm{g})$ is the mass of the final chemically modified material.

\section{SORPTION}

The sorption tests were performed in batch, from the mechanical agitation of flaks containing $0.0250 \mathrm{~g}$ of the sorbent SSA in $10.0 \mathrm{~cm}^{3}$ of VR 5 solution. After the sorption process, the suspension was centrifuged and the dye concentration in the supernatant was determined by spectrophotometry in the uv-vis. All tests were made under pressure and constant agitation at a temperature of $298 \mathrm{~K}$.

In order to verify the $\mathrm{pH}$ influence of the sorption process, the experiment was performed using buffer solution of $\mathrm{pH} 1.0$ to 6.0 (prepared with $\mathrm{KCl}, \mathrm{HCl}, \mathrm{NaOH}$, and $\mathrm{KHC}_{8} \mathrm{H}_{4} \mathrm{O}_{4}$ ), and dye solution at a concentration of $100 \mathrm{mg} \mathrm{dm}^{-3}$. The dye solution was in contact with the sorbent under constant stirring for $24 \mathrm{~h}$, and then the suspension was centrifuged and the supernatant was separated to determine the amount of dye sorbed.

The amount sorbed per gram of sorbent was obtained by the equation: 


$$
\mathrm{q}=\frac{\left(\mathrm{C}_{\mathrm{i}}-\mathrm{C}_{\mathrm{f}}\right) \cdot \mathrm{V}}{\mathrm{W}}
$$

where $\mathrm{C}_{\mathrm{i}}$ and $\mathrm{C}_{\mathrm{f}}$ represent the initial and final concentration of the dye, respectively, $\mathrm{w}$ is the mass of sorbent $(\mathrm{g}), \mathrm{V}$ is the volume of dye solution used $\left(\mathrm{dm}^{3}\right)$, and $\mathrm{q}$ is the amount sorbed per gram of sorbent $\left(\mathrm{mg} \mathrm{g}^{-1}\right)$.

The kinetic study was performed at $\mathrm{pH} 2.0$, which was verified by a $\mathrm{pH}$ study as the one in which maximum sorption occurs. The procedure used was similar to that used in the $\mathrm{pH}$ study, varying only the contact time between 5 and $120 \mathrm{~min}$. The experimental data were fitted to the kinetic models of pseudofirst order (Eq. 3) and pseudo-second order (Eq. 4) (Lagergren 1898, Ho and McKay 1998) as expressed in equation (3) and (4) below:

$$
\begin{gathered}
q_{t}=q_{e}\left(1-\exp \left(-k_{f} t\right)\right) \\
q_{t}=\frac{k_{s} q_{e}^{2} t}{1+q_{e} k_{s} t}
\end{gathered}
$$

where $\mathrm{q}_{\mathrm{e}}$ and $\mathrm{q}_{\mathrm{t}}\left(\mathrm{mg} \mathrm{g}^{-1}\right)$ are the amounts of sorbed metals at equilibrium and at any time, $\mathrm{t}(\mathrm{min})$, respectively, and $\mathrm{k}_{\mathrm{f}}\left(\mathrm{min}^{-1}\right)$ and $\mathrm{k}_{\mathrm{s}}\left(\mathrm{g} \mathrm{mmol}^{-1} \mathrm{~min}^{-1}\right)$ is the sorption rate constant.

Similarly, the experiments were conducted to obtain the sorption isotherm, but varying the concentration of the dye from 20 to $200 \mathrm{mg} \mathrm{dm}^{-3}$ at $\mathrm{pH} 2.0$ and the sorption equilibrium time. The experimental data were fitted to the isothermal models of Langmuir, Freundlich and Temkin (Langmuir 1918, Freundlich 1906, Temkin and Pyzhev 1940), as expressed in equations (5), (6) and (7) below:

$$
\begin{gathered}
q=\frac{K_{L} q_{m} C_{s}}{1+K_{L} C_{s}} \\
q=K_{F} C_{s}^{1 / n} \\
q=\ln \left(K_{T} C_{s}\right)^{\beta}
\end{gathered}
$$

where $\mathrm{C}_{\mathrm{s}}$ is the supernatant concentration after the equilibrium of the system $\left(\mathrm{mg} \mathrm{dm}^{-3}\right), \mathrm{K}_{\mathrm{L}}$ the Langmuir affinity constant $\left(\mathrm{dm}^{3} \mathrm{mg}^{-1}\right)$, and $\mathrm{q}_{\mathrm{m}}$ is the maximum sorption capacity of the material $\left(\mathrm{mg} \mathrm{g}^{-1}\right)$, assuming a monolayer of the sorbate uptake by the sorbent. $\mathrm{K}_{\mathrm{F}}$ is the Freundlich constant related to the sorption capacity $\left[\mathrm{mg} \mathrm{g}^{-1}\left(\mathrm{mg} \mathrm{dm}^{-3}\right)^{-1 / n}\right]$ and $\mathrm{n}$ is the dimensionless Freundlich exponent. $\mathrm{K}_{\mathrm{T}}\left(\mathrm{dm}^{-3} \mathrm{mg}^{-1}\right)$ and $\beta$ are Temkin constants.

\section{RESULTS AND DISCUSSION}

\section{CHARACTERIZATION}

The amount of carboxylic groups introduced on the surface of wood sawdust was determined by titration and is given in the Table I. The results observed are comparable with those found in literature (Gurgel et 
TABLE I

Degree of substitution of the biopolymers.

\begin{tabular}{ccc}
\hline Biopolymer & $\mathrm{Q}_{\mathrm{COOH}}\left(\mathrm{mmol} \mathrm{g}^{-1}\right)$ & $\mathrm{Q}_{\mathrm{COOH}}\left(\mathrm{mg}^{-1} \mathrm{~g}^{-1}\right)$ \\
\hline $\mathrm{WS}$ & $0.15 \pm 0.05$ & $12.47 \pm 0.05$ \\
$\mathrm{SSA}$ & $3.96 \pm 0.10$ & $151.54 \pm 0.10$ \\
\hline
\end{tabular}

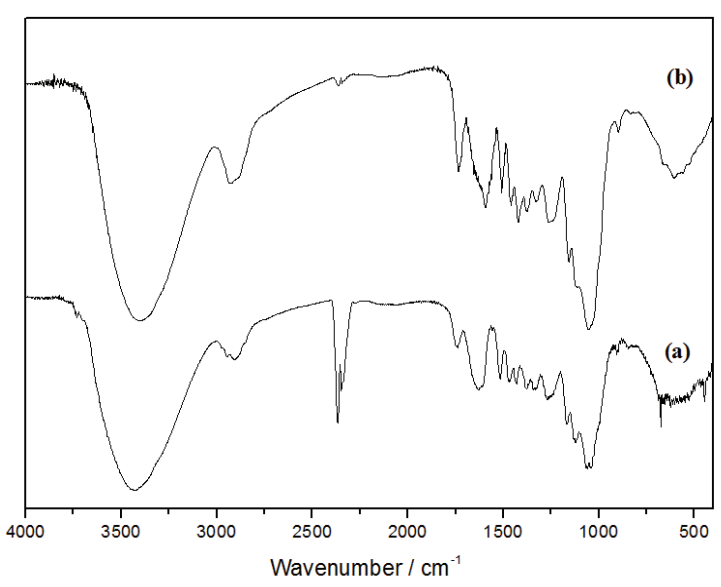

Figure 1 - Infrared spectra of wood sawdust, WS (a) and wood sawdust modified with succinic anhydride, SSA (b).

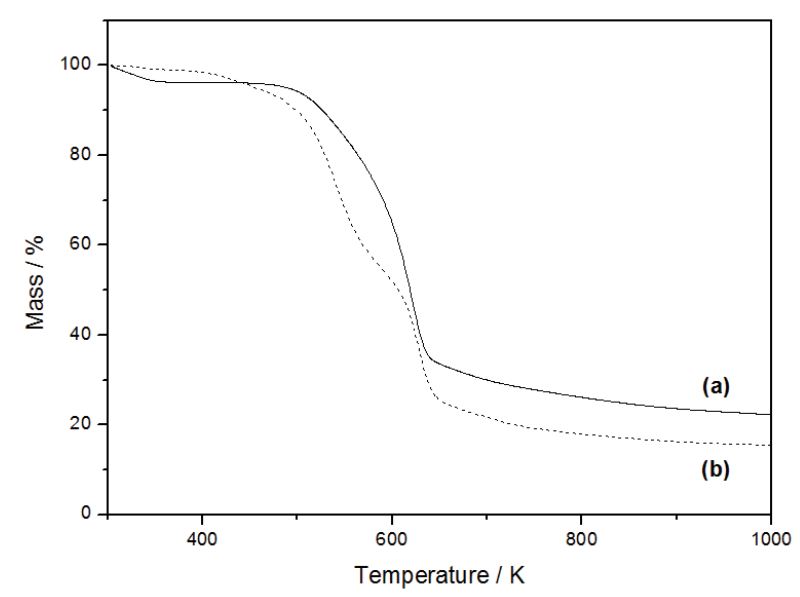

Figure $2-{ }^{13} \mathrm{C}$ NMR spectra of cellulose (a) and wood sawdust modified with succinic anhydride, SSA (b).

al. 2008). It can be verified that there was a considerable increase in the carboxylic group of the modified material, confirming the surface modification of WS, stating that carboxylic groups were introduced to the matrix through reactions with succinic anhydride.

The infrared spectra of wood sawdust (a) and sawdust modified with succinic anhydride (b) are shown in Figure 1. As can be seen, the main bands that appear in the spectra of wood sawdust (a) are: an intense and broad band in the $3000-3700 \mathrm{~cm}^{-1}$ range attributed to the $\mathrm{OH}$ stretching vibrations; the peaks around $2904 \mathrm{~cm}^{-1}$ represented $\mathrm{C}-\mathrm{H}$ stretching vibrations and $\mathrm{CH}_{3}$; the band around $1730 \mathrm{~cm}^{-1}$ might be assigned to the $\mathrm{C}=\mathrm{O}$ stretching vibration, and the strong peaks at $1115-1056 \mathrm{~cm}^{-1}$ represented $\mathrm{C}-\mathrm{OH}$ stretching vibration. The spectra (b) of chemically modified wood sawdust (SSA) is very close to that of the preceding WS, except for the band at $1730 \mathrm{~cm}^{-1}$, which became more intense and is attributed to stretching of the ester carbonyl formed during the modification reaction with succinic anhydride (Gurgel et al. 2008). The nonappearance of the band at $1850 \mathrm{~cm}^{-1}$, which corresponds to anhydride-free, demonstrates the purity of the sorbent (Tserki et al. 2005).

Figure 2 shows the comparison between the ${ }^{13} \mathrm{C}$ NMR spectra of the SSA (b) and cellulose (a), where we can observe the signs that represent the chemical shifts assigned to six carbon atoms present in a monomer unit of cellulose. Signs related to the parts assigned to the crystalline and amorphous carbon 6 are respectively 64 and 55 ppm, and suggest that the hydroxyl groups of complex carbohydrates have been esterified by succinic anhydride (Safou-Tchiama et al. 2007). The signals at 88 and 83 ppm refer to the C4. The region between 75 and $70 \mathrm{pm}$ refers to cabon C2, C3, and C5. The signal at $105 \mathrm{ppm}$ refers to the $\mathrm{C} 1$. In addition to signals common to cellulose, the spectrum (b) of modified wood sawdust still, SSA, shows 


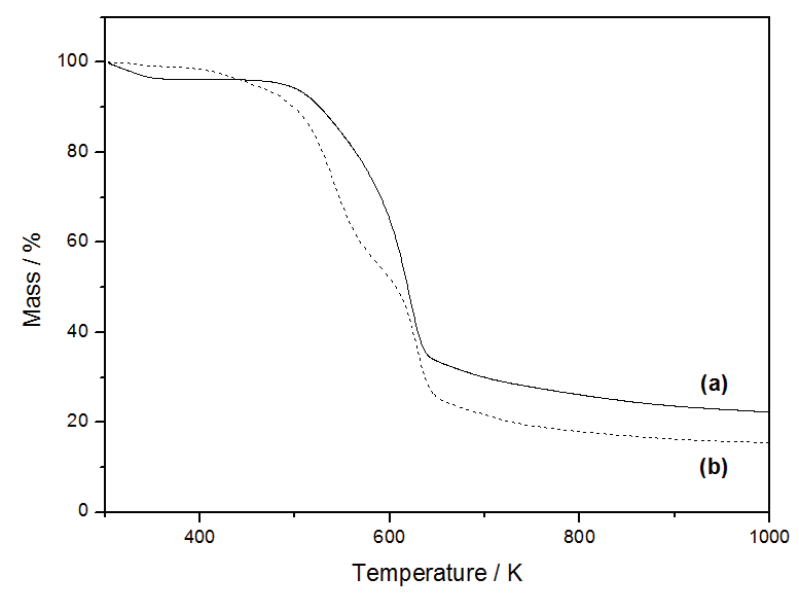

Figure 3 - Thermogravimetric curves for wood sawdust, WS (a) and wood sawdust modified with succinic anhydride, SSA (b).

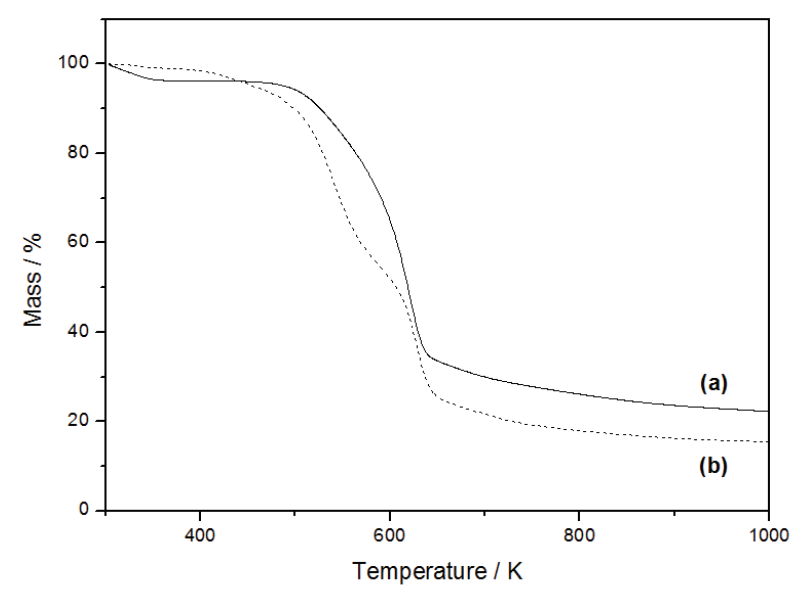

Figure 4 - (a) $\mathrm{pH}_{\mathrm{zpc}}$ and (b) Influence of $\mathrm{pH}$ on the sorption of the VR 5 dye by wood sawdust modified with succinic anhydride, SSA.

peaks that appear in the region at $172 \mathrm{ppm}$, related to the carbonyl carbon 7 and 10, and the methylene group at 32 ppm, carbon 8 and 9, shows the occurrence of reaction with succinic anhydride (Chang and Chang 2001).

The thermogravimetric curves of wood sawdust (a) and SSA (b) are shown in Figure 3. Compared to the precursor, the modified material showed similar behavior regarding decomposition, and the SSA presented a stage of mass loss higher than the wood sawdust. The first stage of mass loss, which occurs at $363 \mathrm{~K}$, is attributed to the release of water physically adsorbed on the surface of the material, which corresponds to $1.23 \%$ of the weight of the modified material (Han et al. 2010). The second stage of decomposition in this material occurs at temperatures between 423 and $593 \mathrm{~K}$, and is associated with the decomposition of lignocellulosic materials, which consist of mixture of cellulose, hemicelluloses, and lignin that corresponded to mass of $44.68 \%$ (Tserki et al. 2005). The third stage of decomposition occurs at temperatures between 593 and $645 \mathrm{~K}$, where there is a mass loss of $18.47 \%$ that can be attributed to the output of the carboxylic group. The decomposition is not complete, and the residue formed was not characterized, but may correspond to carbon formation. Degradation process occurring in these reactions, such as condensation of the hydroxyl carbons 2 and 3, the conversion of acids and esters directly to carbon dioxide and also cellulose fiber loss, is due to decrease of the polymer chains. The chemical modification of wood sawdust kept the resistance to thermal degradation as expected.

POINT ZERO CHARGE $\left(\mathrm{PH}_{\mathrm{PZC}}\right)$ AND PH INFLUENCE OF THE SORPTION

The study of point zero charge $\left(\mathrm{pH}_{\mathrm{PZC}}\right)$ of a material is an important parameter to be considered because it provides useful information about the behavior of charges on the surface of sorbents as a function of $\mathrm{pH}$. Figure $4 \mathrm{a}$ shows the graph of $\mathrm{pH}=\mathrm{pH}_{\mathrm{i}}-\mathrm{pH}_{\mathrm{f}}$ as a function of $\mathrm{pH}_{\mathrm{i}}$, which describes the behavior of the surface charge of the SSA. As shown, the $\mathrm{pH}_{\mathrm{PZC}}$ of the SSA is 6.4, which is the $\mathrm{pH}$ where the surface positive and negative charges are equivalent. It can be stated that the sorption of positive charge is favored when the $\mathrm{pH}$ is higher than the $\mathrm{pH}_{\mathrm{PZC}}$ of the material, while the sorption of negative charge, on the other hand, is favored when the $\mathrm{pH}$ is lower than the $\mathrm{pH}_{\mathrm{PZC}}$ (Vieira et al. 2009, 2011). So it is expected that the sorption of the 

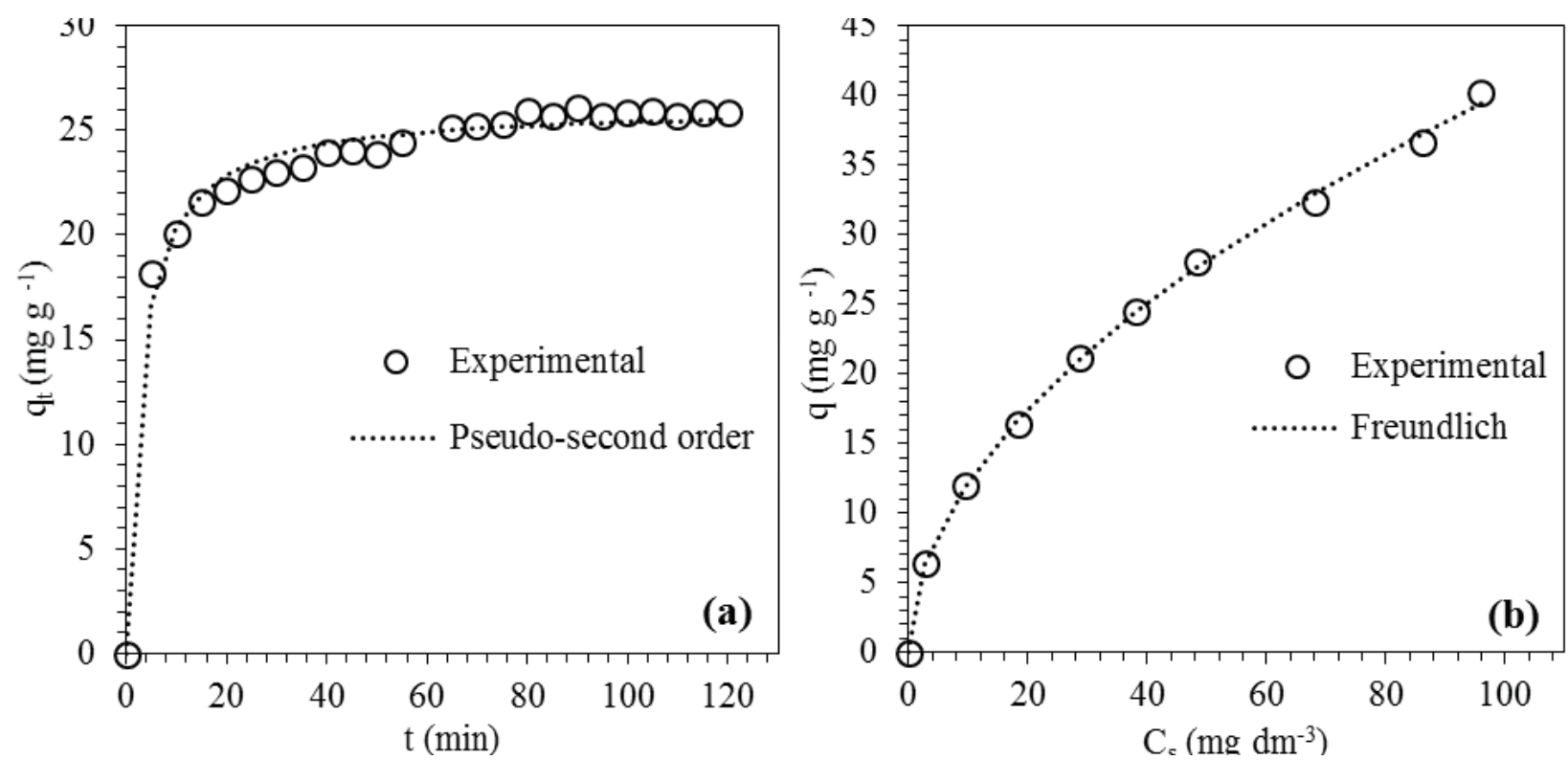

Figure 5 - Effect of contact time (a) and concentration (b) on sorption of the VR 5 dye by wood sawdust modified with succinic anhydride, SSA. Temperature $=323 \mathrm{~K}, \mathrm{pH} 2.0$.

TABLE II

Parameter obtained by non-linear fit of the kinetic models.

\begin{tabular}{ccc}
\hline Parameter & Pseudo-first order & Pseudo-second order \\
\hline $\mathrm{q}_{\mathrm{e}} / \mathrm{mg} \mathrm{g}^{-1}$ & 24.7 & 26.1 \\
\hline $\mathrm{k}_{\mathrm{f}} / \mathrm{min}^{-1}$ & 0.20 & - \\
\hline $\mathrm{k}_{\mathrm{s}} / \mathrm{g} \mathrm{mg}^{-1} \mathrm{~min}^{-1}$ & - & 0.01 \\
\hline $\mathrm{R}_{2}$ & 0.94 & 0.98 \\
\hline$\chi^{2}$ & 1.74 & 0.41 \\
\hline
\end{tabular}

VR 5 dye by SSA is favored at $\mathrm{pH}$ values lower than the $\mathrm{pH}_{\mathrm{PZC}}$ of the sorbent. This trend was confirmed by studying the influence of $\mathrm{pH}$ on sorption, as shown in Figure 4b. The SSA sorption capacity for the VR 5 dye is higher at $\mathrm{pH} 2.0$, since at this $\mathrm{pH}$ the surface of the SSA is protonated and is therefore favorable for sorption of anionic species.

\section{KINETICS AND EQUILIBRIUM}

Figure 5a describes the behavior of sorption as a function of time at $\mathrm{pH}$ 2.0, which was defined as optimal for sorption. From these isotherms it is clearly evidenced that the equilibrium in aqueous solution is reached after 90 min of contact between VR 5 and the suspended SSA.

Experimental data to establish the time required for the sorption equilibrium were fitted to non-linear mathematical equations of the pseudo-first and peudo-second order to examine the mechanism that controls the sorption process. A good correlation of kinetic data explains the sorption mechanism of the dye in the solid phase (Wu et al. 2001). The data obtained from kinetic models are listed in Table II. As observed, the pseudo-first order model presented low coefficients of determination $\left(\mathrm{R}^{2}\right)$ and is also followed by a high chi-square value $\left(\chi^{2}\right)$, compared to the experimental data. In contrast, the pseudo-second order model 
TABLE III

Parameter obtained by non-linear fit of the isotherm models.

\begin{tabular}{cccc}
\hline Parameter & Langmuir & Freundlich & Temkin \\
\hline $\mathrm{q}_{\mathrm{m}} / \mathrm{mg} \mathrm{g}^{-1}$ & 55.6 & - & - \\
\hline $\mathrm{K}_{\mathrm{L}} / \mathrm{dm}^{3} \mathrm{mg}^{-1}$ & 0.02 & - & - \\
\hline $\mathrm{K}_{\mathrm{F}} / \mathrm{mg} \mathrm{g}^{-1}\left(\mathrm{dm}^{3} \mathrm{mg}^{-1}\right)^{1 / \mathrm{n}}$ & - & 3.71 & - \\
\hline $\mathrm{K}_{\mathrm{T}} / \mathrm{dm}^{-3} \mathrm{mg}^{-1}$ & - & - & 2.31 \\
\hline $\mathrm{n}$ & - & 1.93 & - \\
\hline $\boldsymbol{\beta}$ & - & - & 2.15 \\
\hline $\mathrm{R}^{2}$ & 0.97 & 0.99 & 0.98 \\
\hline$\chi^{2}$ & 3.42 & 0.25 & 2.05 \\
\hline
\end{tabular}

showed a high coefficient of determination $\left(\mathrm{R}^{2}\right)$ and yet low chi-square value $\left(\chi^{2}\right)$, which indicates that the model is satisfactory to explain the kinetic behavior of this sorption system. Usually the sorption fits this model when the initial concentration of the sorbate is not excessively high (Azizian 2004). Other studies also show a tendency for kinetic models of pseudo-second order to explain the mechanism of dye sorption by lignocellulosic material (Vieira et al. 2009, 2010, 2011).

As shown in Figure 5b, the values of amount adsorbed $(q)$ increase with increasing supernatant concentration of dye, which indicates an exponential distribution without a tendency to saturation of the surface. According to the Giles classification, this isotherm is of type H3, which implies large slope at low concentrations indicating strong preferential sorption of the solute (Giles et al. 1960). The experimental results were used to fit the Langmuir, Freundlich, and Temkin models, and the parameters found are shown in Table III. The determination coefficients $\left(\mathrm{R}^{2}\right)$ calculated show that the three adsorption models tested relatively represented well the adsorption on SSA.

\section{CONCLUSIONS}

The surface modification of WS through succinic anhydride was evidenced by characterization techniques. The analysis of IR, ${ }^{13} \mathrm{C}$ NMR and titration of the acidic groups showed that carboxylic groups were introduced onto the surface of wood sawdust. The thermogravimetric analysis indicated that there was little change to the thermal resistance of the material, which remains stable up to temperatures close to $393 \mathrm{~K}$. The material obtained can be used as a sorbent for the VR 5dye. The sorption of the dye proved to be $\mathrm{pH}$ dependent, being favored under acidic conditions. At $\mathrm{pH} 2.0$, the active sites existing in the SSA are protonated, since $\mathrm{pH}_{\mathrm{PZC}}$ for this solid is 6.4. The most favorable sorption at $\mathrm{pH} 2.0$ suggests that the mechanism involves the interaction between the sulfonic groups of dye and the protonated active sites of the sorbent. The system obeys the kinetic model of pseudo-second order and was well adjusted to the adsorption models of Langmuir, Freundlich and Temkin.

\section{ACKNOWLEDGMENTS}

The authors are indebted to Coordenação de Aperfeiçoamento de Pessoal de Nível Superior (CAPES) and to Fundação de Amparo à Pesquisa e ao Desenvolvimento Científico e Tecnológico do Maranhão (FAPEMA) for financial support and to Indústria de Toalhas São Carlos for its donation of the dye samples. 


\section{REFERENCES}

AZIZIAN S. 2004. Kinetic models of sorption: a theoretical analysis. J Colloid Interf Sci 276: 47-52.

BHARATHI KS AND RAMESH ST. 2013. Removal of dyes using agricultural waste as low-cost adsorbents: a review. Appl Water Sci 3: 773-790.

CHANG ST AND CHANG HT. 2001. Comparisons of the photostability of esterified wood. Polym Degrad Stabil 71: 261-266.

ÇIÇEK F, ÖZER D, ÖZER A AND ÖZER A. 2007. Low cost removal of reactive dyes using wheat bran. J Hazard Mater 146: 408-416.

CRINI G. 2006. Non-conventional low-cost adsorbents for dye removal: A review. Bioresource Technol 97: 1061-1085.

DINÇER AR, GÜNEŞ Y, KARAKAYA N AND GÜNEŞ E. 2007. Comparison of activated carbon and bottom ash removal of reactive dye from aqueous solution. Bioresour Technol 98: 834-839.

FREUNDLICH HMF. 1906. Over the adsorption in solution. J Phys Chem 57: 385-470.

GILES CH, MACEWAN TH, NAKHWA SN AND SMITH D. 1960. A system of classification of solution adsorption isotherms, and its use in diagnosis of adsorption mechanisms and in measurement of specific surface areas of solids. J Chem Soc: $3973-$ 3993.

GONG R, JIN Y, CHEN F, CHEN J AND LIU Z. 2006. Enhanced malachite green removal from aqueous solution by citric acid modified rice straw. J Hazard Mater 137: 865-870.

GONG R, JIN Y, CHEN J, HU Y AND SUN J. 2007. Removal of basic dyes from aqueous solution by sorption on phosphoric acid modified rice straw. Dyes Pigm 73: 332-337.

GUPTA VK AND SUHAS. 2009. Application of low-cost adsorbents for dye removal - A review. J Environ Manage 90: $2313-2342$.

GURGEL LVA, FREITAS RP AND GIL LF. 2008. Adsorption of $\mathrm{Cu}(\mathrm{II}), \mathrm{Cd}(\mathrm{II})$, and $\mathrm{Pb}$ (II) from aqueous single metal solutions by sugarcane bagasse and mercerized sugarcane bagasse chemically modified with succinic anhydride. Carbohydr Polym 74 : 922-929.

HAN R, ZHANG L, SONG C, ZHANG M, ZHU H AND ZHANG LJ. 2010. Characterization of modified wheat straw, kinetic and equilibrium study about copper ion and methylene blue adsorption in batch mode. Carbohydr Polym 79: 1140-1149.

HO YS AND MCKAY G. 1998. The kinetics of sorption of basic dyes from aqueous solution by sphagnum moss peat. Can J Chem Eng 76: 822-827.

KADIRVELU K, KAVIPRIYA M, KARTHIKA C, RADHIKA M, VENNILAMANI N AND PATTABHI S. 2003. Utilization of various agricultural wastes for activated carbon preparation and application for the removal of dyes and metal ions from aqueous solutions. Bioresour Technol 87: 129-132.

KYZAS GZ AND KOSTOGLOU M. 2014. Green Adsorbents for Wastewaters: A Critical Review. Materials 7: $333-364$.

LAGERGREN S. 1898. About the theory of so-called adsorption of soluble substances. Handlingar 24: 1-39.

LANGMUIR I. 1918. The sorption of gases on plane surfaces of glass, mica and platinum. J Am Chem Soc 40: 1361-1368.

LASZLO JA AND DINTZIS FR. 1994. Crop resides as lon-exchange materials. Treatment of soybean hull and sugar beet fiber (pulp) with epichlorohydrin to improve cation-exchange capacity and physical stability. J Appl Polym Sci 52: 531-538.

MAO J, WON SW, VIJAYARAGHAVAN K AND YUN YS. 2010. Immobilized citric acid-treated bacterial biosorbents for the removal of cationic pollutants. Chem Eng J 162: 662-668.

MELO JCP, SILVA FILHO EC, SANTANA SAA AND AIROLDI C. 2011. Synthesized cellulose/succinic anhydride as an ion exchanger. Calorimetry of divalent cations in aqueous suspension. Thermochim Acta 524: 29-34.

MOUSSAVI G AND BARIKBIN B. 2010. Biosorption of chromium (VI) from industrial wastewater onto pistachio hull waste biomass. Chem Eng J 162: 893-900.

NOROOZI B, SORIAL GA, BAHRAMI H AND ARAMI M. 2007. Equilibrium and kinetic adsorption study of a cationic dye by a natural adsorbent-Silkworm pupa. J Hazard Mater 139: 167-174.

OKIEIMEN FE AND OKUNDAYE JN. 1989. Removal of Cadmium and Copper Ions from Aqueous-Solutions with Thiolated Maize (Zea-Mays) Cob Meal. Biol Waste 30: 225-230.

RAFATULLAH M, SULAIMAN O, HASHIM R AND AHMAD A. 2010. Adsorption of methylene blue on low-cost adsorbents: A review. J Hazard Mater 177: 70-80.

RANDALL JM, HAUTALA E AND MCDONALD G. 1978. Binding Of Heavy-Metal Ions By Formaldehyde-Polymerized Peanut Skins. J Appl Polym Sci 22: 379-387.

SAFOU-TCHIAMA R, JÉSO B, AKAGAH AG, SÈBE G AND PÉTRAUD M. 2007. A preliminary survey of the interfacial bonding of some tropical hardwoods towards succinic anhydride and 2-octen-1-yl succinic anhydride molecules: Impact of lignin and carbohydrate polymers structure on the chemical reactivity. Ind Crop Prod 26: 173-184.

SALLEH MAM, MAHMOUD DK, KARIM WAWA AND IDRIS A. 2011. Cationic and anionic dye adsorption by agricultural solid wastes: A comprehensive review. Desalination 280: 1-13. 
SANGHI R AND VERMA P. 2013. Decolorisation of aqueous dye solutions by low-cost adsorbents: a review. Color Technol 129: 85-108

SHARMA N, TIWARI DP AND SINGH SK. 2012. Decolourisation of Synthetic Dyes by Agricultural Waste- A Review. Int J Sci Eng Res 3: 1-10.

SHEN D, FAN J, ZHOU WI, GAO B, YUE Q AND KANG Q. 2009. Adsorption kinetics and isotherm of anionic dyes onto organobentonite from single and multisolute systems. J Hazard Mater 172: 99-107.

SULAK MT, DEMIRBAS E AND KOBYA M. 2007. Removal of Astrazon Yellow 7GL from aqueous solutions by adsorption onto wheat bran. Bioresour Technol 98: 2590-2598.

TEMKIN MI AND PYZHEV V. 1940. Kinetics of ammonia synthesis on promoted iron catalyst. Acta Physicochim 12: $327-356$.

TSERKI V, MATZINOS P, KOKKOU S AND PANAYIOTOU C. 2005. Novel biodegradable composites based on treated lignocellulosic waste flour as filler. Part I. Surface chemical modification and characterization of waste flour. Composites Part A 36: 965-974.

VIEIRA AP, SANTANA SAA, BEZERRA CWB, SILVA HAS, CHAVES JAP, MELO JCP, SILVA FILHO EC AND AIROLDI C. 2009. Kinetics and thermodynamics of textile dye adsorption from aqueous solutions using babassu coconut mesocarp. $\mathrm{J}$ Hazard Mater 166: 1272-1278.

VIEIRA AP, SANTANA SAA, BEZERRA CWB, SILVA HAS, CHAVES JAP, MELO JCP, SILVA FILHO EC AND AIROLDI C. 2011. Removal of textile dyes from aqueous solution by babassu coconut epicarp (Orbignya speciosa). Chem Eng J 173: 334-340.

VIEIRA AP, SANTANA SAA, BEZERRA CWB, SILVA HAS, MELO JCP, SILVA FILHO EC AND AIROLDI C. 2010. Copper sorption from aqueous solutions and sugar cane spirits by chemically modified babassu coconut (Orbignya speciosa) mesocarp. Chem Eng J 161: 99-105.

WARTELLE LH AND MARSHALL WE. 2000. Citric acid modified agricultural by-products as copper ion adsorbents. Adv Environ Res 4: 1-7.

WU FC, TSENG RL AND JUANG RS. 2001. Kinetic modeling of liquid-phase adsorption of reactive dyes and metal ions on chitosan. Water Res 35: 613-618.

YAGUB MT, SEN TK, AFROZE S AND ANG HM. 2014. Dye and its removal from aqueous solution by adsorption: A review. Adv Colloid Interface Sci 209: 172-184. 